\title{
Mapping environmental and climate variations by GMT: a case of Zambia, Central Africa
}

\author{
Polina Lemenkova
}

Schmidt Institute of Physics of the Earth, Russian Academy of Sciences. Department of Natural Disasters, Anthropogenic Hazards and Seismicity of the Earth. Laboratory of Regional Geophysics and Natural Disasters (Nr. 303). Bolshaya Gruzinskaya Str. 10/1, Moscow, 123995, Russian Federation. ORCID ID: https://orcid.org/0000-0002-5759-1089

Email: pauline.lemenkova@gmail.com Tel.: +007-916-298-37-19

\begin{abstract}
Zambia recently experienced several environmental threats from climate change such as droughts, temperature rise and occasional flooding and they all affect agricultural sustainability and people wellbeing through negative effects on plants and growing crops. This paper is aimed at showing variations in several climate and environmental parameters in Zambia showing spatial variability and trends in different regions of Zambia's key environmental areas (Zambezi River and tributaries), Livingstone near the Victoria Falls and central region with Muchinga Mountains. A series of 10 maps was plotted using data from TerraClimate dataset: precipitation, soil moisture, Palmer Drought Severity Index (PDSI), downward surface shortwave radiation, vapor pressure deficit and anomalies, potential and actual evapotranspiration and wind speed with relation to the topographic distribution of elevations in Zambia plotted using GEBCO/SRTM data. The data range of the PDSI according to the index values ranged from minimum at -5.7 to the maximum at 16.6 and mean at 7.169 , with standard deviation at 4.278. The PDSI is effective in quantifying drought in long-term period. Because PDSI index applies temperature data and water balance model, it indicates the effect of climate warming on drought by correlation with potential evapotranspiration. The maximum values for soil moisture of Zambia show minimum at $1 \mathrm{~mm} / \mathrm{m}$, maximum at $413 \mathrm{~mm} / \mathrm{m}$, mean at $173 \mathrm{~mm} / \mathrm{m}$. This study is technically based on using the Generic Mapping Tools (GMT) as cartographic scripting toolset. The paper contributes to the environmental monitoring of Zambia by presenting a series of climate and environmental maps that are beneficial for agricultural mapping of Zambia.
\end{abstract}

Keywords: evapotranspiration, radiation, soil moisture, precipitation, drought, vapor pressure

\section{Introduction}

\section{Background}

The geography of Zambia (Fig. 1) is characterized by its location in central-southern Africa with a tropical climate and developed river network. Hydrologically, Zambia hosts the two major river basins: 1) the Zambezi River in the center, west, and south that controls ca. $75 \%$ of the country's watershed with its major tributaries: Kafue, Luangwa, Kabompo, Lungwebungu among the most important ones and the Victoria Falls in the southern border of the country with Zimbabwe; 2) the Congo River in the 
north controlling the remaining $25 \%$ of the catchment. Minor rivers are presented in the country including Kaleya near Lake Kariba in southern Zambia (Chisola et al. 2020). The topography of Zambia is dominated by high plateaus with occasional hills and mountains, dissected by river valleys forming the fluvial network of the country.

The agriculture of Zambia is largely regulated by its location within the tropics in Sub-Saharan Africa with extensively grown drought tolerant crops resisting to the extreme climate: millet, maize, sorghum and cassava (Blanc, 2012). At the same time, Zambia is experiencing the effects of climate change. In general, climate variability has a tendency to increase in southern Africa, which is caused by extreme regional conditions. Climate in southern and central regions of Africa including Zambia generally gets drier and experiences more extreme weather conditions, particularly risk of droughts and floods (Mubaya et al. 2012).

Thus, according to the spatio-temporal data analysis from the Zambia Meteorological Department (1976 to 2016), significant changes in precipitation were reported in the region of the Victoria Falls in southern Zambezi River. Other climate hazards included the increase in temperature, extreme rainfall patterns, and decline in rainfall and fluctuation in water flow levels at the Victoria Falls (Dube and Nhamo, 2018).

Environmental and climate studies have long been of practical importance to support agricultural monitoring for the effective land management and development of the sustainable growth and wellbeing existing of local population (Djurfeldt and Hillbom, 2016). Since agrarian communities have low resilience to climate and environmental extremes, they are especially sensitive to droughts and low rainfalls (Foster, 1992; Mason et al. 2010). Facing such environmental challenges, Zambia implemented national climate change adaptation governance and policies in practice for ecological strategies (Funder and Mweemba, 2019). Other protecting actions include the organization of agricultural cooperatives coupled with effective extension services for faster and greater adoption of the improved techniques to resist droughts, environmental hazards and to accelerate agricultural technologies (Manda et al. 2020).

According to Libanda et al. (2020) who explored the long-term spatio-temporal changes in precipitation and temperature over Zambia for the period 1950-2016, the precipitation has been decreasing by $1.1 \mathrm{~mm} \mathrm{yr}^{-1}$ across the country showing the abrupt change in the trend of its distribution. At the same time, the temperature has been increasing at a rate of $0.01^{\circ} \mathrm{C} \mathrm{yr}^{-1}$. Both factors taken together contributes to the possibility of drought in Zambia. Social consequences of climate change, environmental and natural disasters and drought include the decreased overall satisfaction with life and well-being (Choongo et al. 2021). As a practical example illustrating this statement: drought decreases crop harvest in Zambia, which may lead to increased poverty and unemployment of the local people. Other hazards include toxic chemicals from the Copperbelt region known for copper mining and 
geological exploration in the north of Zambia that can deteriorate the quality of soils and cause pollution of rivers (Banda and Sichilongo, 2006).

Floods are becoming frequent and severe in selected regions of Zambia. This requires developing adaptation strategies for people exposed to flooding disasters (Mabuku et al. 2019). In view of this, visualizing environmental and climate variables through mapping helps to analyze and predict flood duration and dimensions of land affected by floods to determine how rural household can adapt to flooding hazards. On the other hand, rainfall, temperature and water level have direct effects of on fisheries ecosystems and people who derive livelihoods from fish yield (Ng'onga et al. 2019). Variations in climate and environmental setting have social consequences affecting people.

\section{Study aim and objective}

The aim of the present study is to visualize, explain and analyze spatial variations of several environmental and climate parameters over Zambia by employing Generic Mapping Tools (GMT) developed by Wessel et al. (2019) and freely available online (https://www.generic-mapping-tools.org/) to distinguish the regions of the country most affected by the climate and environmental effects. To achieve this aim, the objective of this study was to map a series of the environmental and climate datasets from TerraClimate (Abatzoglou et al. 2018) in the area of Zambia, central-southern Africa. Technical goal was to demonstrate the effectiveness of the usage of scripting technical in cartographic data processing applying multi-source data to the agricultural and environmental studies.

The novelty and practical importance of this study consists in a multi-disciplinary approach which applied advanced cartographic method of scripting mapping by GMT for environmental studies of Zambia that has not been presented so far in the existing literature. Practical purpose is to present new interpretations of the climate variability for the area of Zambia using TerraClimate dataset for 2018.

\section{Materials and Methods}

\section{Data}

Main data source used in this study include the TerraClimate high-resolution $\left(1 / 24^{\circ}\right.$, i.e. approximately 4-km) global dataset that presents monthly data in raster format showing climate and climatic water balance for global terrestrial surfaces (Abatzoglou et al. 2018). The selected files in netCDF format have been produced for each year presenting a variable combination of the monthly data in the TerraClimate dataset. The topographic map in Figure 1 has been plotted using GEBCO grid of the Earth's relief (Schenke, 2016), largely used in geosciences and topographic mapping (Lemenkova, 2020d, 2020e). This study is based on the methodology of GMT developed by Wessel et al. (2019) with 
case applications documented in relevant studies (Gauger et al. 2007; Lemenkova, 2020a, 2020b, 2021a).

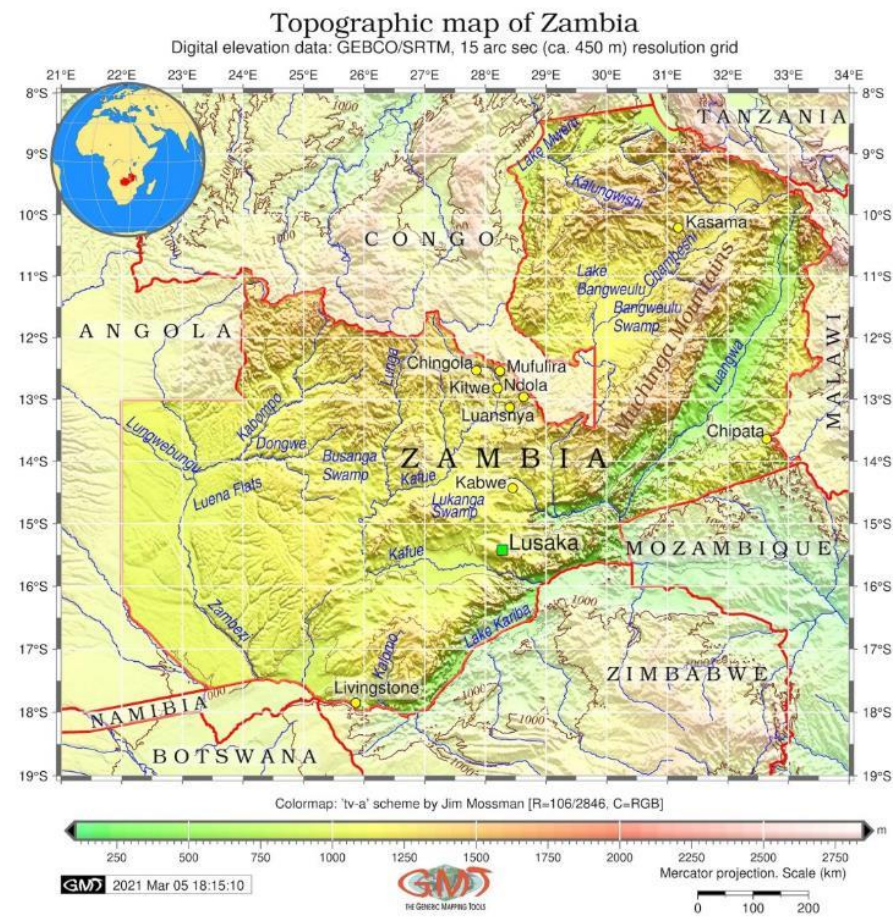

Figure 1. Topographic map of Zambia. Source: author.

\section{Methods}

The approach of GMT is based on a modular cartographic approach with special parameters defined and used for plotting each cartographic element, which makes it easy to add new layers on the raster map (Lemenkova 2020c). Compared to the mainstream GIS approaches based on graphic user interface (GUI) or other approaches in Earth science (e.g. Klaučo et al. 2014, 2017, Lemenkov and Lemenkova, 2021b; Suetova et al. 2005a, 2005b; Lemenkova, 2011; Lemenkova et al. 2012), the GMT can be considered as a generalization of the programming approach with respect to the cartography where geospatial data are processed using scripting techniques.

\section{Results and Discussion}

This study implemented the environmental and climate modelling of the raster data from the opensource TerraClimate dataset and processed using GMT. For compatibility reasons, the maps are presented in Mercator projection for the 2018 and the spatial extant is limited to $21^{\circ} \mathrm{E}-34^{\circ} \mathrm{E}, 19^{\circ} \mathrm{S}-8^{\circ} \mathrm{S}$. 
The GMT scripts have been run for each map from the presented series, therefore this approach leaves many options to the application in further similar studies of the environmental models. Figure 1 shows a topographic map of Zambia with visualized variations in heights in the study area. The elevation range has been inspected by Geospatial Data Abstraction Library (GDAL) using 'gdalinfo' utility for each map, to check up the statistical data. According to GDAL, the topography over the study area varies from minimum at $106 \mathrm{~m}$ to a maximum at $2846 \mathrm{~m}$, with a mean at $1073.898 \mathrm{~m}$, and standard deviation at $268.713 \mathrm{~m}$.

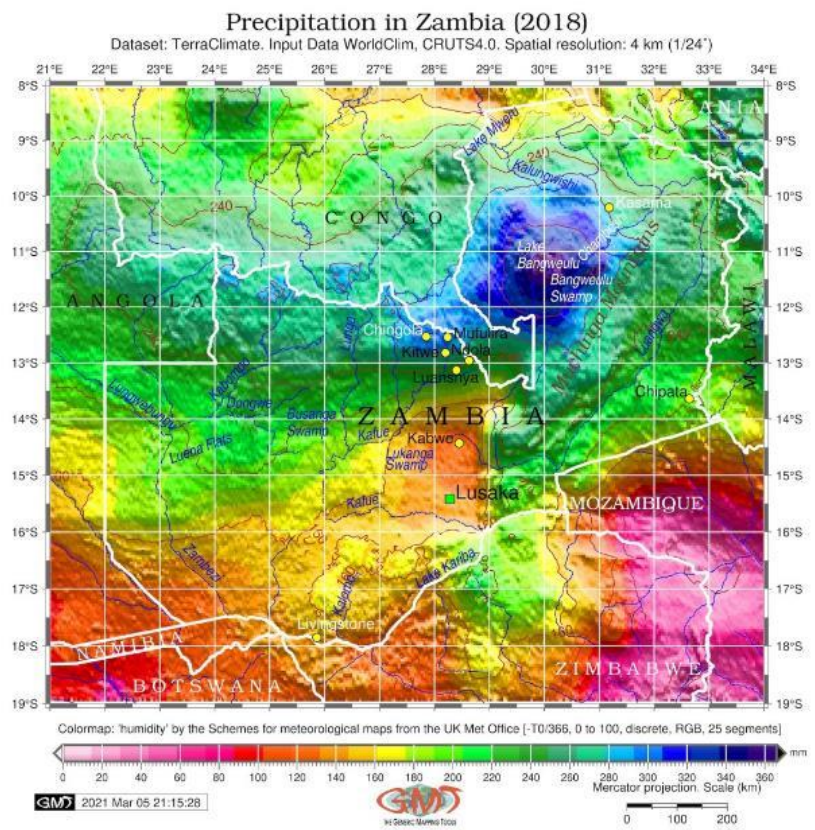

Figure 2. Precipitation map of Zambia. Source: author

Figure 2 demonstrates the precipitation in Zambia varying from minimum at $124 \mathrm{~mm}$, to maximum at $362 \mathrm{~mm}$, with a mean of $195.476 \mathrm{~mm}$ and standard deviation of $43.011 \mathrm{~mm}$. The maximum of data can be seen in the area of Lake Bangweulu where the precipitation exceeds $360 \mathrm{~mm}$ (dark blue colors in Figure 2), while the minimum is around Kabwe region in central Zambia (orange colors in Figure 2). Relatively wet area is notable in Muchinga Mountains in the northeast of Zambia (262-280 mm, emerald colors), which divide the drainage basins of the two major rivers of Zambia: the Zambezi River (discharging into the Indian Ocean) and Congo River (Atlantic Ocean 
Next, Figure 3 shows the mapping results for a soil moisture in Zambia. The soil moisture is driven with a precipitation, temperature and properties of soil (such as permeability, porosity, density of soils) that enforces a correspondence between climate, geologic and environmental variables and in turn affects vegetation. As output the map obtains the maximum values for the soil moisture of Zambia as follows: minimum at $1 \mathrm{~mm} / \mathrm{m}$, maximum at $413 \mathrm{~mm} / \mathrm{m}$, mean at $173 \mathrm{~mm} / \mathrm{m}$.

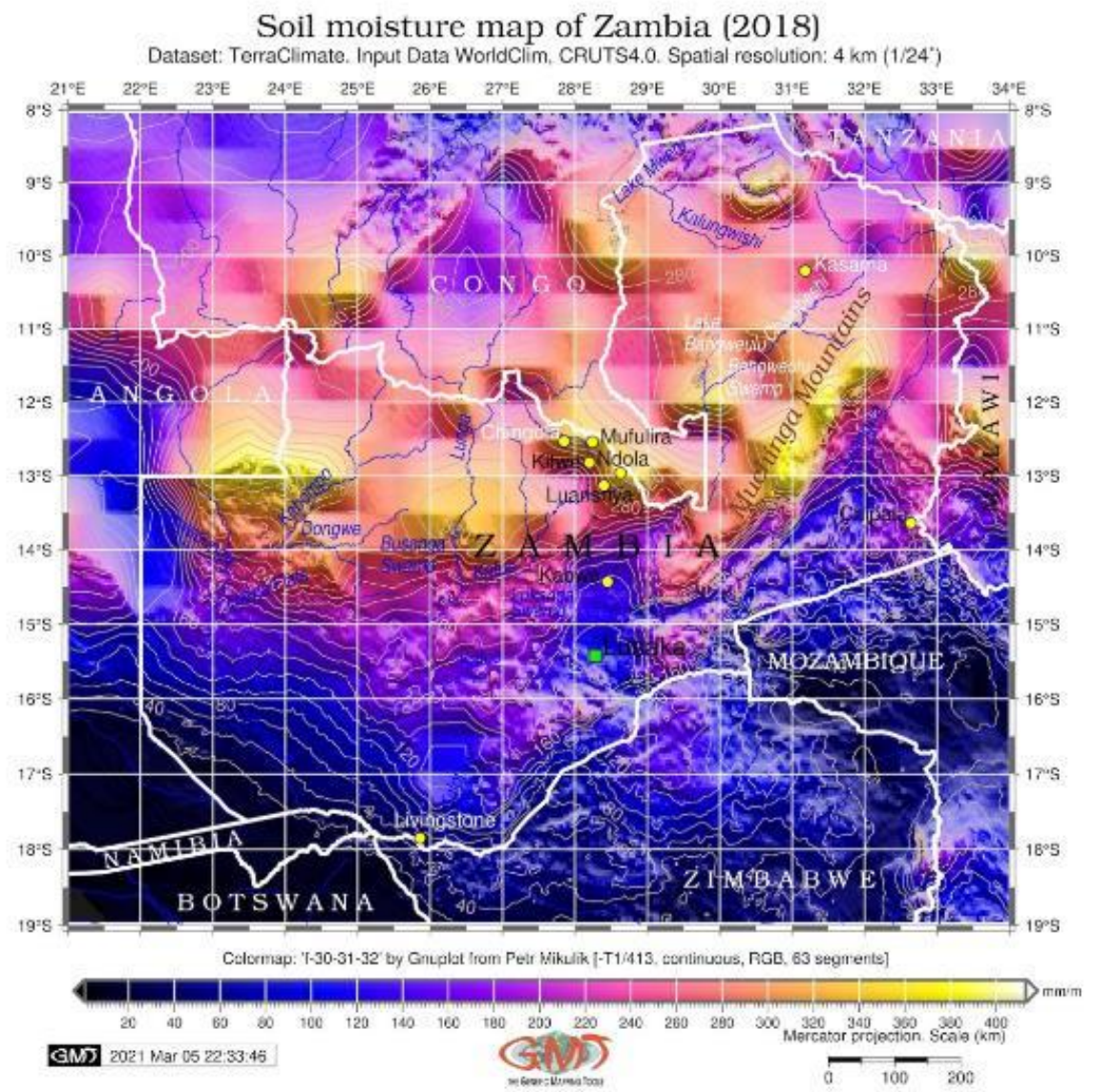

Figure 3. Soil moisture map of Zambia. Source: author.

Figure 4 demonstrates the Palmer Drought Severity Index (PDSI) that shows the intensity of drought over the study area based on the data from the temperature and precipitation used to estimate relative dryness. 


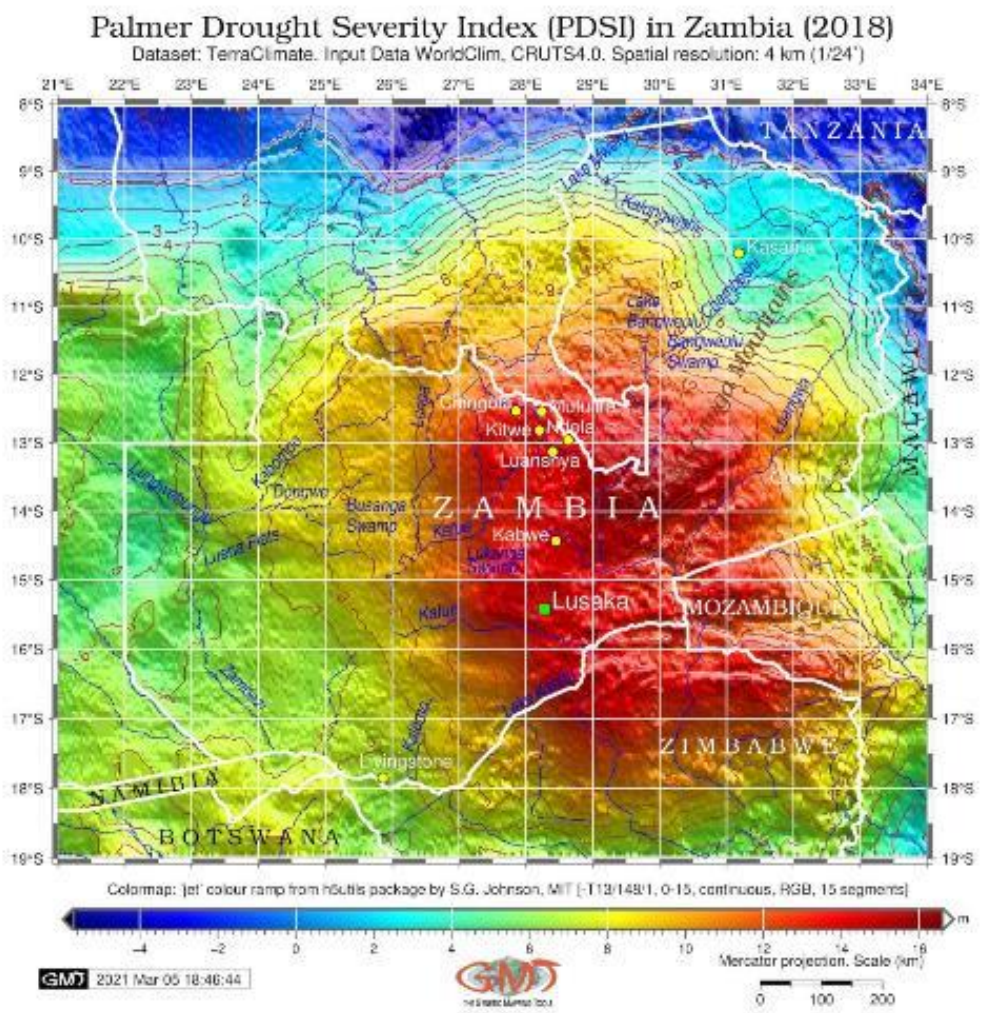

Figure 4. Palmer Drought Severity Index (PDSI) in Zambia. Source: author.

The data range according to the index values from minimum at -5.7 to the maximum at 16.6 and mean at 7.169, with standard deviation at 4.278. The PDSI is effective in quantifying drought in long-term period. Because PDSI index applies temperature data and water balance model, it indicates the effect of climate warming on drought by correlation with potential evapotranspiration. The classification of humidity conditions according to the PDSI index utilizes available data on temperature and precipitation in Zambia to estimate relative dryness over the country. It is a standardized index that in general ranges from -10 (dry) to +10 (wet). Hence the analysis of the map enables the following interpretation: 4.00 <PDSI extremely humid, while data -4.00> PDSI. The extreme drought are notable for the border regions with Tanzania while the wet areas are notable in the central regions of the country with welldeveloped hydrological network: Lake Kariba, along the rivers Kafure, Luangwa, Lukanga Swamp area, and around the capital of Lusaka. These regions are colored red in Figure 4.

Detailed observation of soil moisture and PDSI in Zambia has a practical importance both for environmental and environmental studies, because the PDSI is a good indicator of the fluctuations in 
soil moisture. Analysis of spatio-temporal relationships of PDSI with other maps in the presented series shows variability of the hydrological, environmental and climate relations in Zambia. Moreover, a correlation of the PDSI with topographic setting of the country shows the effects of the relief of Zambia on the variability of precipitation.

Figure 5 shows results of the mapping downward surface shortwave radiation in Zambia corresponding to estimate of the total amount of shortwave radiation (direct and diffuse) that reaches the Earth's surface. One can see that in Zambia, the downward surface shortwave radiation gives a general trend increasing southward with the maximal at the Livingstone in the south of the country. The data range is detected as follows: from minimum at $124 . \mathrm{Wm}^{-2}$ to a maximum at $281 \mathrm{Wm}^{-2}$, with mean $=195.476 \mathrm{Wm}^{-2}$ and a standard deviation at $43.011 \mathrm{Wm}^{-2}$.

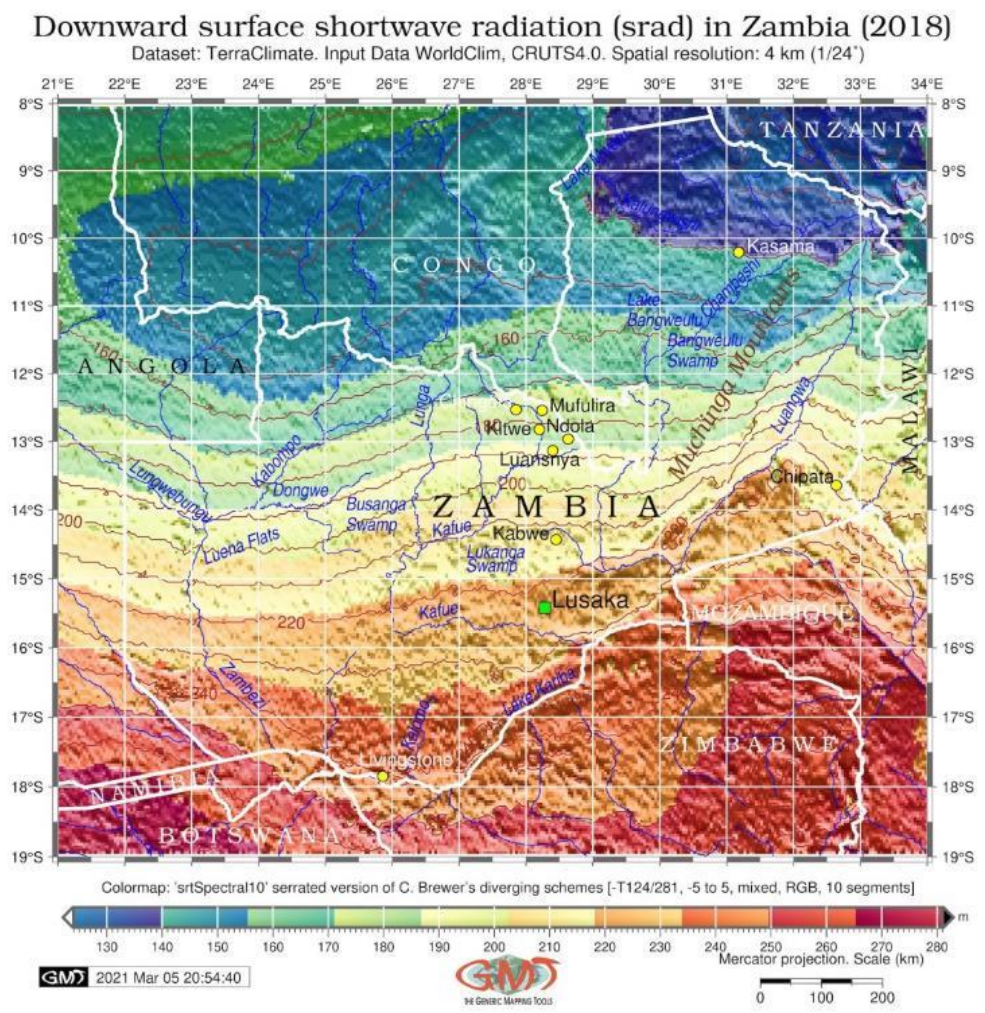

Figure 5. Downward surface shortwave radiation in Zambia. Source: author.

Figure 6 shows the vapor pressure deficit with following data variation: minimum at $0.080 \mathrm{kPa}$, maximum at $2.160 \mathrm{kPa}$, mean at $0.885 \mathrm{kPa}$, and standard deviation at $0.330 \mathrm{kPa}$. It shows the climate parameters of difference between the amount of moisture in the air and the amount of moisture the air 
can hold if it is saturated. Hence, for the environmental studies it demonstrates the difference between the actual water vapor pressure and the saturation water vapor pressure at a particular temperature which regulates plant health.

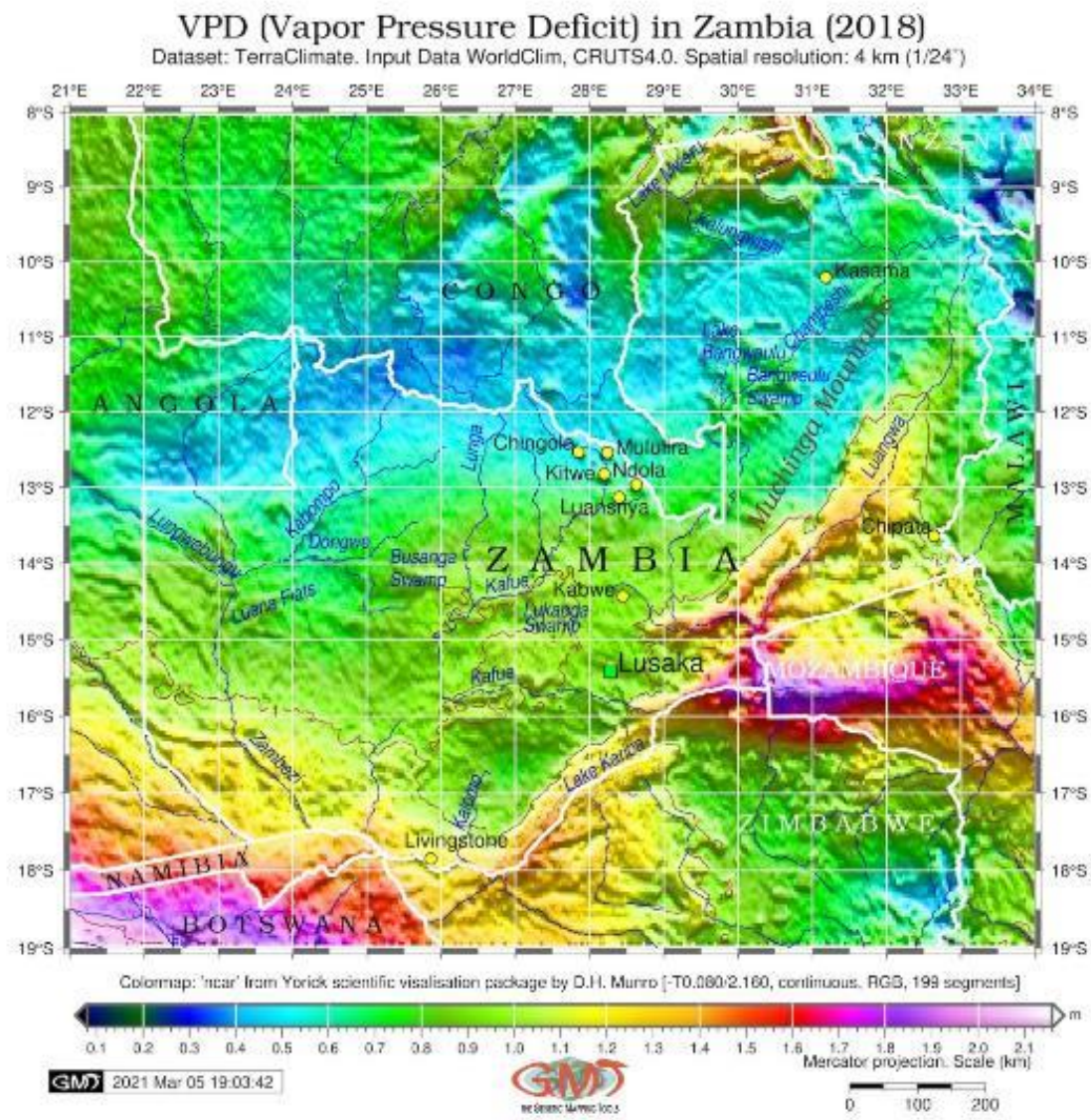

Figure 6. Vapor pressure deficit in Zambia. Source: author.

Figure 7 depicts vapor pressure anomaly distribution in Zambia with data range from minimum at 1.280 $\mathrm{kPa}$ to maximum at $2.820 \mathrm{kPa}$, mean at $2.171 \mathrm{kPa}$, and standard deviation at $0.181 \mathrm{kPa}$. This map of vapor pressure anomalies shows some correlation between the precipitation and vapor pressure deficit, with excessive precipitation corresponding with higher values of vapor pressure anomalies and drought PDSI correlating with negative anomalies. 


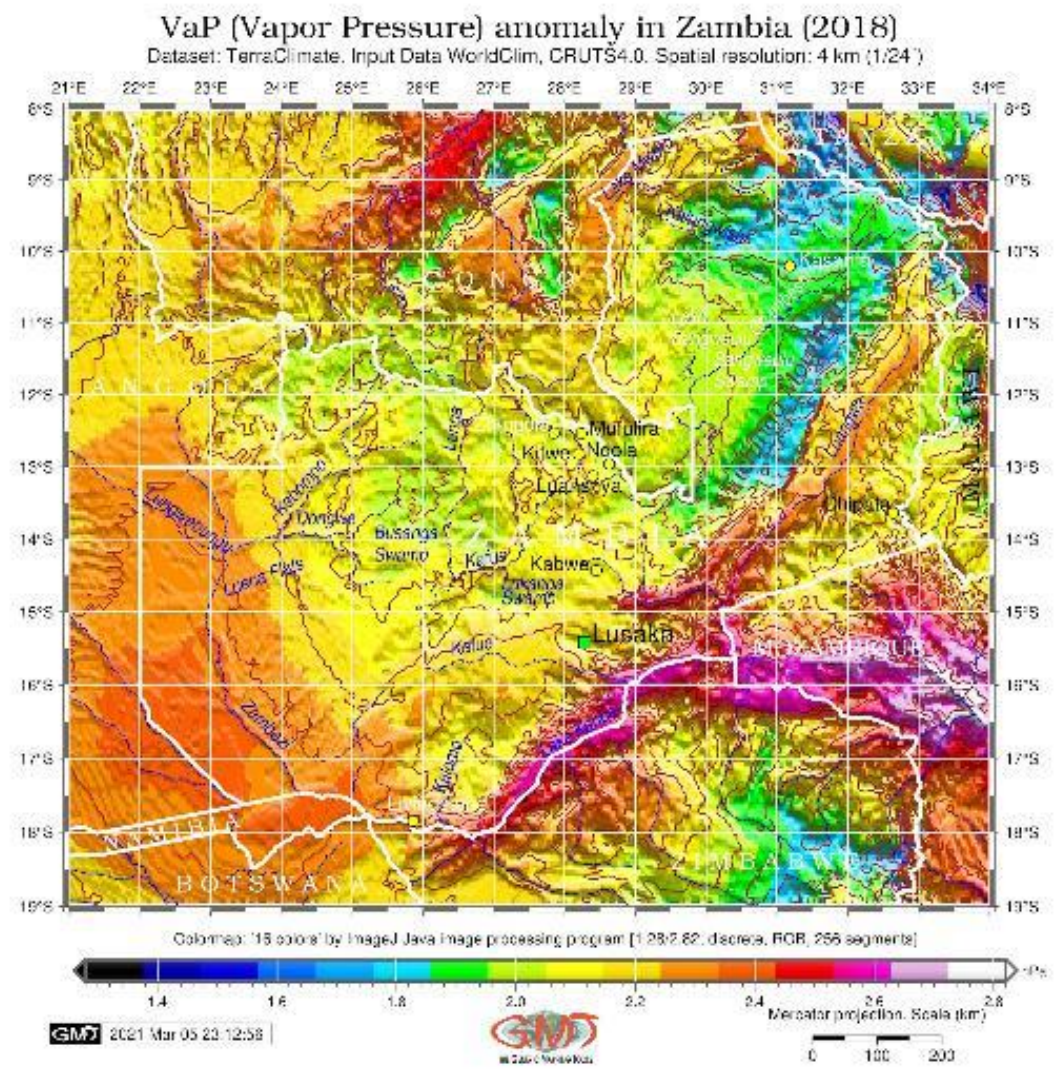

Figure 7. Vapor pressure anomaly distribution in Zambia. Source: author.

Figure 8 shows the map of potential evapotranspiration. As can be seen from Figure 8 , the general trend inclines southwards, with higher values in the southern borders of Zambia with Mozambique, Zimbabwe, Namibia and southern Angola. Different regional climate, vegetation, precipitation and environmental setting create different values of evapotranspiration. The data range is from minimum at $65 \mathrm{~mm} /$ year, maximum at $187 \mathrm{~mm} /$ year, mean at $117.7 \mathrm{~mm} /$ year, and standard deviation at 25.536 $\mathrm{mm} / \mathrm{year}$.

Figure 9 illustrates the actual evapotranspiration which differs over Zambia from minimum at 13. $\mathrm{kPa}$, to maximum at $148 \mathrm{kPa}$, with mean at $73.225 \mathrm{kPa}$, and standard deviation (StdDev) at 28.295 $\mathrm{kPa}$. The actual evapotranspiration is an important component of the hydrological cycle and physical processes in natural environmental ecosystems. For plants, the importance of actual evapotranspiration can be illustrated by its structure that points at the relationship between water and energy in the cycles of soil, land surface and atmosphere over Zambia. 


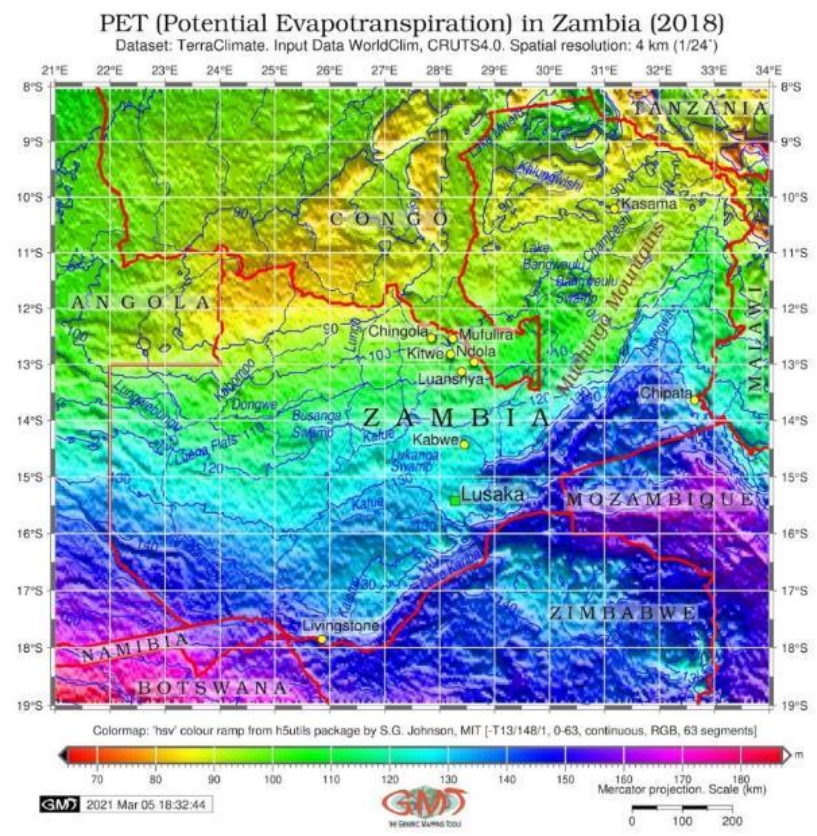

Figure 8. Potential evapotranspiration in Zambia. Source: author.

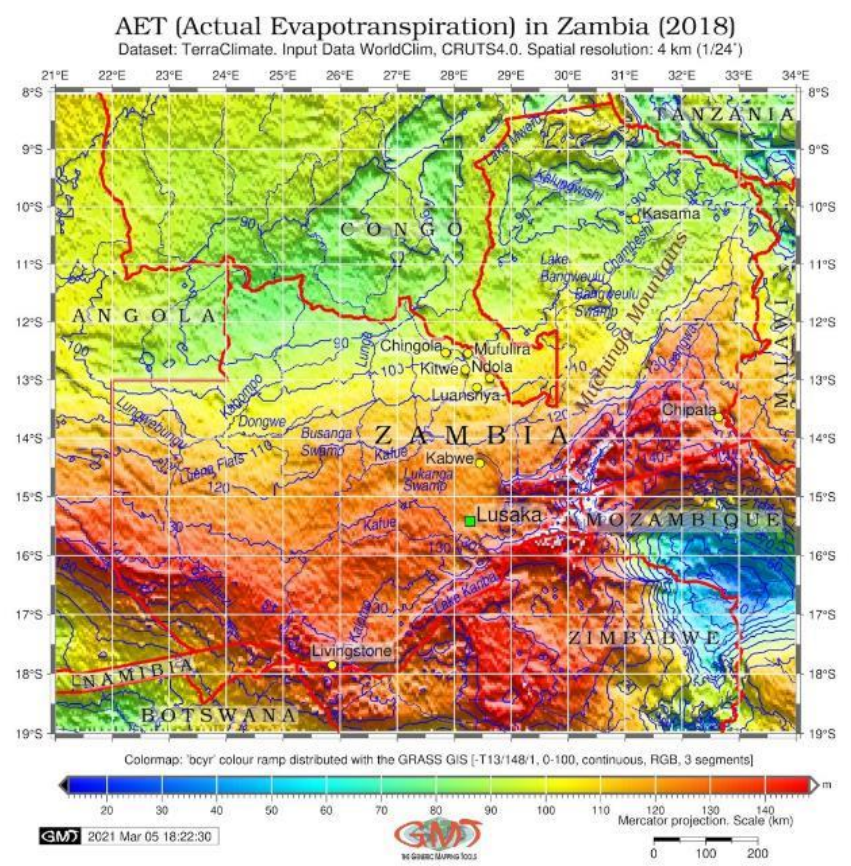

Figure 9. Actual evapotranspiration in Zambia. Source: author. 
Finally, Figure 10 shows the distribution of the wind speed over the country with general tendency of increase in wind speed in south-eastward direction. The general data variation is from minimum at 1.1 $\mathrm{m} / \mathrm{s}$, Maximum=3.1 m/s, Mean=1.996 m/s, and standard deviation (StdDev) at $0.352 \mathrm{~m} / \mathrm{s}$. Higher values (bright orange colors in Figure 9) are notable around Lusaka (around $3 \mathrm{~m} / \mathrm{s}$ ).

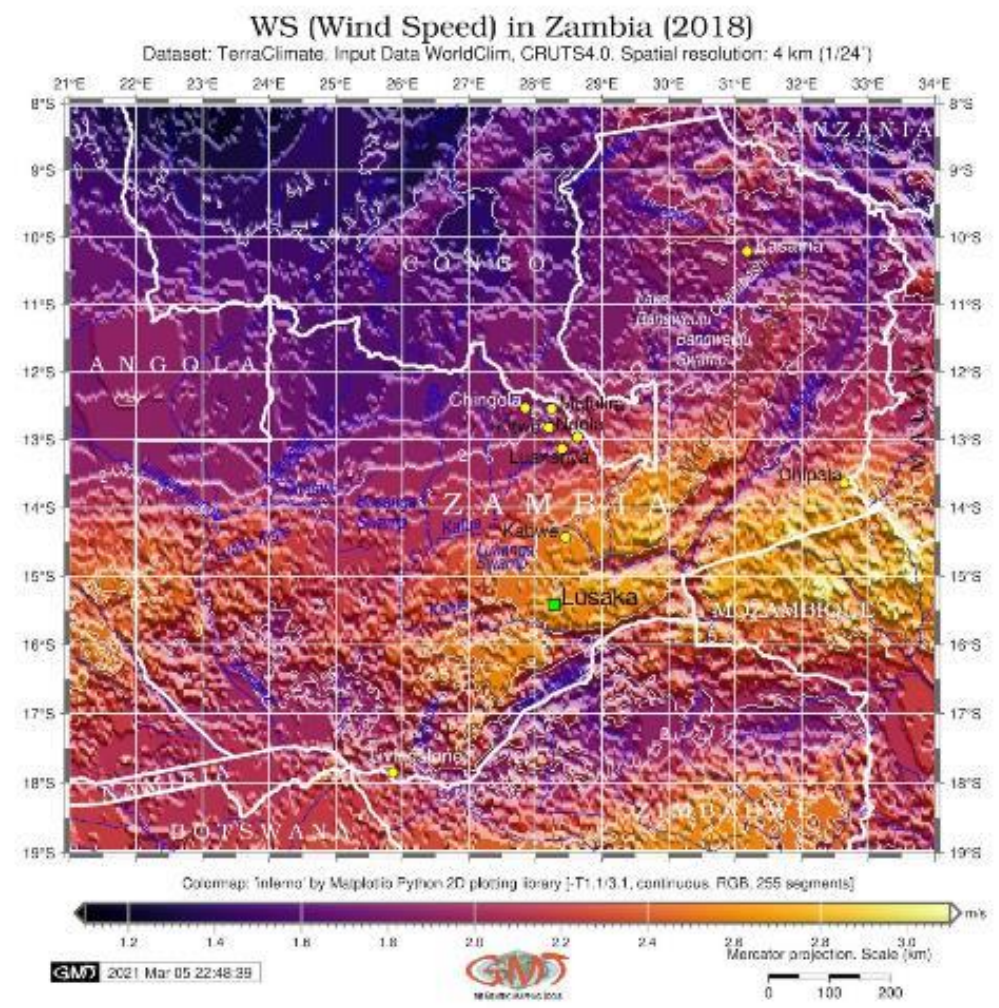

Figure 10. Wind speed map of Zambia. Source: author.

Mapping environmental and climate data can serve as information for seasonal drought forecasting, which is valuable for farmers in Zambia (Maggio and Sitko, 2019). Several environmental studies proposed measures to cope with environmental and climate hazards in Zambia, such as sustainable agricultural interventions, which should focus on low risk technologies with minimal future costs, the reduced utilization of pesticide and herbicide and other mineral fertilizers that have negative environmental effects (Mubanga and Umar, 2020). Others suggested comparative evaluation of the environmental impact assessment legislation using comparative analysis of Zambia with neighboring countries (Mubanga and Kwarteng, 2020). Supporting these studies, this work contributes to the environmental studies of Zambia by cartographic data visualization. 
Various measures of climate risks mitigation in Zambia are proposed with regards to mitigation of the agricultural, social and environmental effects. This include assessing climate risk and adaptation, developing plan strategies aimed at agricultural sustainability in case of drought, developing schemes of future resilience for various scenarios of climate change including drought and flooding, climate risk assessment, implementation, monitoring and evaluation using data analysis (Vincent and Colenbrander, 2018). Others are proposing strategy of conservation agriculture to minimize soil movement, reduce tillage, protect crops and growing plants which is effective for the cases of moisture stress (Thierfelder and Wall, 2009). Some approaches report food security strategies in Zambia related to agricultural monitoring (Resnick et al. 2018). Yet another approach is reported with attempts to improve productivity in marginal farming areas of Zambia (Somanje et al. 2017).

The importance of this study, contributing to the previous ones, consists in the presented series of maps of Zambia made using the approach of automatization in cartography. Automatization and machine learning advances cartographic workflow through plotting maps faster and more accurate through the computer-based data processing (Lemenkova, 2021b; Schenke \& Lemenkova, 2008). Since the GMT algorithms of data processing require specific syntax, the scripting mapping approach can serve as a sophisticated alternative to more user-friendly GIS mapping based on graphical user interface (GUI), traditionally used in geoscience (Ng'onga et al. 2019; Klaučo et al. 2013a, 2013b; Lemenkova, 2013; Gohl et al. 2006a, 2006b).

\section{Conclusion}

This study presented a series of the environmental and climate maps of Zambia modeled with GMT approach, implemented using the TerraClimate open-source datasets and tested for the 2018 time period. The maps demonstrated such variables as Palmer Drought Severity Index (PDSI), downward surface shortwave radiation, Vapor pressure deficit and anomaly, actual and potential evapotranspiration, wind speed, soil moisture and precipitation, showing spatial distribution of these values for the territory of Zambia in April of 2018. The use of GMT required application of several modules, which have been technically adopted from the existing studies (e.g. Lemenkova, 2019a, 2019b), plus some optional cartographic parameters modified to refine the maps.

The presented approach of scripting mapping is capable of generating a series of the thematic environmental and climate maps of Zambia in an accurate, precise and fast way due to the technical advantages of the machine-based graphics. Several climate variables have been demonstrated using various color palettes to highlight the differences and variations in the data across the country using the open source TerraClimate data which interpolates the high-spatial resolution climatological normals from the WorldClim dataset. 
While GMT is graphically and computationally efficient and can rapidly process raster grids, this approach has limitations in classic cartography, as it requires learning scripting syntax, which is similar to the programming languages in its fundamental principle of console-based data processing, such as Python and R, or linear programming models (Wineman and Crawford, 2017; Lemenkova, 2019c, 2019d) or markup languages such as TeX (Lemenkov and Lemenkova, 2021a). The visualization of several thematic data as an integrated approach in one study enables to analyze correlations between the variables to evaluate complex effects that be performed with GMT approach, albeit at a much higher scripting effort compared to the traditional GIS.

\section{Acknowledgement}

The author expresses her gratitude to the editor and two anonymous reviewers for providing useful comments and suggestions that allowed to improve quality of the article.

\section{References}

Abatzoglou J, Dobrowski S, Parks S, Hegewisch KC. 2018: TerraClimate, a high-resolution global dataset of monthly climate and climatic water balance from 1958-2015. Scientific Data 5: 170191. https://doi.org/10.1038/sdata.2017.191

Banda SF, Sichilongo K. 2006: Analysis of the level of comprehension of chemical hazard labels: A case for Zambia. Science of The Total Environment 363(1-3): 22-27. https://doi.org/10.1016/j.scitotenv.2005.10.011

Blanc E. 2012: The impact of climate change on crop yields in sub-Saharan Africa. American Journal of Climate Change 1(1): 1-13. https://doi.org/10.4236/ajcc.2012.11001

Chisola MN, van der Laan M, Bristow KL. 2020: A landscape hydrology approach to inform sustainable water resource management under a changing environment. A case study for the Kaleya River Catchment, Zambia. Journal of Hydrology: Regional Studies 32: 100762. https://doi.org/10.1016/j.ejrh.2020.100762

Choongo P, Eijdenberg EL, Lungu J, Chabala M, Taylor TK, Masurel E. 2021: Chapter 10 - The Influence of Environmental Pollution and Drought on the Satisfaction With Life of Entrepreneurs in Zambia's Mining Sector. In: Taha Chaiechi (Eds). Economic Effects of Natural Disasters, Academic Press, 147-160.

Dube K, Nhamo G. 2018: Climate variability, change and potential impacts on tourism: Evidence from the Zambian side of the Victoria Falls. Environmental Science \& Policy 84: 113-123. https://doi.org/10.1016/j.envsci.2018.03.009 
Djurfeldt AA, Hillbom E. 2016: Pro-poor agricultural growth - Inclusion or differentiation? Village level perspectives from Zambia. Geoforum 75: 220-233. https://doi.org/10.1016/j.geoforum.2016.08.002

Foster S. 1992: Zambia: Drought in Monze. The Lancet 340(8817): 476-477. https://doi.org/10.1016/0140-6736(92)91786-8

Funder M, Mweemba CE. 2019: Interface bureaucrats and the everyday remaking of climate interventions: Evidence from climate change adaptation in Zambia. Global Environmental Change 55: 130-138. https://doi.org/10.1016/j.gloenvcha.2019.02.007

Gauger S, Kuhn G, Gohl K, Feigl T, Lemenkova P, Hillenbrand C. 2007: Swath-bathymetric mapping. Reports on Polar and Marine Research 557: 38-45. https://doi.org/10.6084/m9.figshare.7439231

Gohl K, Eagles G, Udintsev G, Larter RD, Uenzelmann-Neben G, Schenke H.-W, Lemenkova P, Grobys J, Parsiegla N, Schlueter P, Deen T, Kuhn G, Hillenbrand C.-D. 2006a: Tectonic and sedimentary processes of the West Antarctic margin of the Amundsen Sea embayment and PineIsland Bay. 2nd SCAR Open Science Meeting, 12-14 July 2006, Hobart, Tasmania, Australia. https://doi.org/10.6084/m9.figshare.7435484

Gohl K, Uenzelmann-Neben G, Eagles G, Fahl A, Feigl T, Grobys J, Just J, Leinweber V, Lensch N, Mayr C, Parsiegla N, Rackebrandt N, Schlüter P, Suckro S, Zimmermann K, Gauger S, Bohlmann H, Netzeband G, Lemenkova P. 2006b: Crustal and Sedimentary Structures and Geodynamic Evolution of the West Antarctic Continental Margin and Pine Island Bay. Expeditionsprogramm Nr. 75 ANT XXIII/4 ANT XXIII/5, 11-12.

Klaučo M, Gregorová B, Stankov U, Marković V, Lemenkova P. 2013a: Determination of ecological significance based on geostatistical assessment: a case study from the Slovak Natura 2000 protected area. Open Geosciences 5(1): 28-42. https://doi.org/10.2478/s13533-012-0120-0

Klaučo M, Gregorová B, Stankov U, Marković V, Lemenkova P. 2013b: Interpretation of Landscape Values, Typology and Quality Using Methods of Spatial Metrics for Ecological Planning. Environmental and Climate Technologies, October 14, 2013. Riga, Latvia.

Klaučo M, Gregorová B, Stankov U, Marković V, Lemenkova P. 2014: Landscape metrics as indicator for ecological significance: assessment of Sitno Natura 2000 sites, Slovakia. In: Ecology and Environmental Protection, March 19-20, 2014, Minsk, Belarus, 85-90.

Klaučo M, Gregorová B, Koleda P, Stankov U, Marković V, Lemenkova P. 2017: Land planning as a support for sustainable development based on tourism: A case study of Slovak Rural Region. Environmental Engineering and Management Journal 2(16), 449-458. https://doi.org/10.30638/eemj.2017.045 
Lemenkova P. 2011: Seagrass Mapping and Monitoring Along the Coasts of Crete, Greece. M.Sc. Thesis. Netherlands: University of Twente. https://doi.org/10.13140/RG.2.2.16945.22881

Lemenkov V, Lemenkova P. 2021a: Using TeX Markup Language for 3D and 2D Geological Plotting. Foundations of Computing and Decision Sciences 46(3): 43-69. https://doi.org/10.2478/fcds2021-0004

Lemenkov V, Lemenkova P. 2021b: Measuring Equivalent Cohesion Ceq of the Frozen Soils by Compression Strength Using Kriolab Equipment. Civil and Environmental Engineering Reports, 31(2): 63-84. https://doi.org/10.2478/ceer-2021-0020

Lemenkova P, Promper C, Glade T. 2012: Economic Assessment of Landslide Risk for the Waidhofen a.d. Ybbs Region, Alpine Foreland, Lower Austria. In: Eberhardt, E., Froese, C., Turner, A. K. and Leroueil, S. (Eds.). Protecting Society through Improved Understanding. 11th International Symposium on Landslides \& the 2nd North American Symposium on Landslides \& Engineered Slopes (NASL), June 2-8, 2012. Canada, Banff, 279-285. https://doi.org/10.6084/m9.figshare.7434230

Lemenkova P. 2013: Monitoring Changes in Agricultural Landscapes of Central Europe, Hungary: Application of ILWIS GIS for Image Processing. In: Conference Proceedings, 12th EAGE International Conference on Geoinformatics - Theoretical and Applied Aspects. Ukraine, Kiev, May 13-16. https://doi.org/10.3997/2214-4609.20142479

Lemenkova P. 2019a: GMT Based Comparative Analysis and Geomorphological Mapping of the Kermadec and Tonga Trenches, Southwest Pacific Ocean. Geographia Technica 14(2): 39-48. https://doi.org/10.21163/GT_2019.142.04

Lemenkova P. 2019b: Geomorphological modelling and mapping of the Peru-Chile Trench by GMT. Polish Cartographical Review 51(4): 181-194. https://doi.org/10.2478/pcr-2019-0015

Lemenkova P. 2019c: Statistical Analysis of the Mariana Trench Geomorphology Using R Programming Language. Geodesy and Cartography 45(2): 57-84. https://doi.org/10.3846/gac.2019.3785

Lemenkova P. 2019d: Testing Linear Regressions by StatsModel Library of Python for Oceanological Data Interpretation. Aquatic Sciences and Engineering 34: 51-60. https://doi.org/10.26650/ASE2019547010

Lemenkova P. 2020a: Scripting cartographic methods of GMT for mapping the New Britain and San Cristobal Trenches, Solomon Sea, Papua New Guinea. Revista da Casa da Geografia de Sobral 22(3): 122-142. https://doi.org/10.35701/rcgs.v22n3.717

Lemenkova P. 2020b: Applying Automatic Mapping Processing by GMT to Bathymetric and Geophysical Data: Cascadia Subduction Zone, Pacific Ocean. Journal of Environmental Geography 13(3-4): 15-26. https://doi.org/10.2478/jengeo-2020-0008 
Lemenkova P. 2020c: Insights on the Indian Ocean tectonics and geophysics supported by GMT. Risks and Catastrophes Journal 27(2): 67-83. https://doi.org/10.24193/RCJ2020 12

Lemenkova P. 2020d: GEBCO and ETOPO1 gridded datasets for GMT based cartographic mapping of Hikurangi, Puysegur and Hjort Trenches, New Zealand. Acta Universitatis Lodziensis. Folia Geographica Physica 19: 7-18. https://doi.org/10.18778/1427-9711.19.01

Lemenkova P. 2020e: GEBCO Gridded Bathymetric Datasets for Mapping Japan Trench Geomorphology by Means of GMT Scripting Toolset. Geodesy and Cartography 46(3): 98112. https://doi.org/10.3846/gac.2020.11524

Lemenkova P. 2021a: Exploring structured scripting cartographic technique of GMT for ocean seafloor modeling: A case of the East Indian Ocean. Maritime Technology and Research 3(2): 162-184. https://doi.org/10.33175/mtr.2021.248158

Lemenkova P. 2021b: Data-driven insights into correlation among geophysical setting, topography and seafloor sediments in the Ross Sea, Antarctic. Caderno de Geografia 31(64): 1-20. https://doi.org/0.5752/p.2318-2962.2021v31n64p1

Libanda B, Bwalya K, Nkolola NB, Chilekana N. 2020: Quantifying long-term variability of precipitation and temperature over Zambia. Journal of Atmospheric and Solar-Terrestrial Physics 198: 105201. https://doi.org/10.1016/j.jastp.2020.105201

Mabuku MP, Senzanje A, Mudhara M, Jewitt GPW, Mulwafu WO. 2019: Strategies for coping and adapting to flooding and their determinants: A comparative study of cases from Namibia and Zambia. Physics and Chemistry of the Earth, Parts $A / B / C$, 111: 20-34. https://doi.org/10.1016/j.pce.2018.12.009

Maggio G, Sitko N. 2019: Knowing is half the battle: Seasonal forecasts, adaptive cropping systems, and the mediating role of private markets in Zambia. Food Policy 89: 101781. https://doi.org/10.1016/j.foodpol.2019.101781

Manda J, Khonje MG, Alene AD, Tufa AH, Abdoulaye T, Mutenje M, Setimela P, Manyong V. 2020: Does cooperative membership increase and accelerate agricultural technology adoption? Empirical evidence from Zambia. Technological Forecasting and Social Change 158: 120160. https://doi.org/10.1016/j.techfore.2020.120160

Mason NM, Jayne TS, Chapoto A, Myers RJ. 2010: A Test of the New Variant Famine Hypothesis: Panel Survey Evidence from Zambia. World Development 38(3): 356-368. https://doi.org/10.1016/j.worlddev.2009.10.004

Mubanga FC, Umar BB. 2020: Environmental discounting behaviour of smallholder farmers in Chibombo District, Central Zambia. Land Use Policy 95: 104551. https://doi.org/10.1016/j.landusepol.2020.104551 
Mubanga RO, Kwarteng K. 2020: A comparative evaluation of the environmental impact assessment legislation of South Africa and Zambia. Environmental Impact Assessment Review 83: 106401. https://doi.org/10.1016/j.eiar.2020.106401

Mubaya CP, Njuki J, Mutsvangwa EP, Mugabe FT, Nanja D. 2012: Climate variability and change or multiple stressors? Farmer perceptions regarding threats to livelihoods in Zimbabwe and Zambia. Journal of Environmental Management 102: 9-17. https://doi.org/10.1016/j.jenvman.2012.02.005

Ng'onga M, Kalaba FK, Mwitwa J, Nyimbiri B. 2019: The interactive effects of rainfall, temperature and water level on fish yield in Lake Bangweulu fishery, Zambia. Journal of Thermal Biology 84: 45-52. https://doi.org/10.1016/j.jtherbio.2019.06.001

Resnick D, Haggblade S, Babu S, Hendriks SL, Mather D. 2018: The Kaleidoscope Model of policy change: Applications to food security policy in Zambia. World Development 109: 101-120. https://doi.org/10.1016/j.worlddev.2018.04.004

Schenke HW, Lemenkova P. 2008: Zur Frage der Meeresboden-Kartographie: Die Nutzung von AutoTrace Digitizer für die Vektorisierung der Bathymetrischen Daten in der Petschora-See. Hydrographische Nachrichten 81: 16-21. https://doi.org/10.6084/m9.figshare.7435538

Schenke H. 2016: General Bathymetric Chart of the Oceans (GEBCO). In: Harff J., Meschede M., Petersen S., Thiede J. (eds) Encyclopedia of Marine Geosciences. Encyclopedia of Earth Sciences Series. Springer, Dordrecht. https://doi.org/10.1007/978-94-007-6238-1_63

Somanje AN, Crespo O, Zinyengere N. 2017: Chapter 5 - Conservation Agriculture Among Farmers in Kalomo, Zambia: Potential for Productivity Under Climate Change, Eds: Zinyengere, N., Theodory, T.F., Gebreyes, M., Speranza, C.I. Beyond Agricultural Impacts, Academic Press, 77-99. https://doi.org/10.1016/B978-0-12-812624-0.00005-3

Suetova IA, Ushakova LA, Lemenkova P. 2005a: Geoinformation mapping of the Barents and Pechora Seas. Geography and Natural Resources 4: 138-142. https://doi.org/10.6084/m9.figshare.7435535

Suetova I, Ushakova L, Lemenkova P. 2005b: Geoecological Mapping of the Barents Sea Using GIS. International Cartographic Conference, July 9-16, La Coruna, Spain. https://doi.org/10.6084/m9.figshare.7435529

Thierfelder C, Wall PC. 2009: Effects of conservation agriculture techniques on infiltration and soil water content in Zambia and Zimbabwe. Soil and Tillage Research 105(2): 217-227. https://doi.org/10.1016/j.still.2009.07.007

Vincent K, Colenbrander W. 2018: Developing and applying a five step process for mainstreaming climate change into local development plans: A case study from Zambia. Climate Risk Management 21, 26-38. https://doi.org/10.1016/j.crm.2018.04.005 
Wessel P, Luis JF, Uieda L, Scharroo R, Wobbe F, Smith WHF, Tian D. 2019: The Generic Mapping Tools version 6. Geochemistry, Geophysics, Geosystems 20, 5556-5564. https://doi.org/10.1029/2019GC008515

Wineman A, Crawford EW. 2017: Climate change and crop choice in Zambia: A mathematical programming approach. NJAS - Wageningen Journal of Life Sciences 81, 19-31. https://doi.org/10.1016/j.njas.2017.02.002 


\section{Mapiranje varijacija životne sredine i klime prema GMT-u: slučaj (primer) Zambije, Centralna Afrika}

\section{Polina Lemenkova}

Schmidt Institute of Physics of the Earth, Russian Academy of Sciences. Department of Natural Disasters, Anthropogenic Hazards and Seismicity of the Earth. Laboratory of Regional Geophysics and Natural Disasters (Nr. 303). Bolshaya Gruzinskaya St, 10, Bld. 1, Moscow, 123995, Russian Federation. Email: pauline.lemenkova@gmail.com ORCID ID: https://orcid.org/0000-0002-5759-1089

\section{Izvod}

Ekosistem Zambije doživljava pretnju usled nastalih klimatskih promena, poput suša, porasta temperature i povremenih poplava, a koje utiču na održivost poljoprivrede i dobrobit populacije svojim delovanjem na biljku i uzgoj useva. Cilj ovog rada je prikazati varijacije u nekoliko klimatskih i ekoloških parametara u Zambiji, prikazujući prostornu varijabilnost i trendove u različitim regijama ključnih za ekosistem: reka Zambezi sa pritokama, Livingstone (u blizini vodopada Victoria) i središnjeg regiona Muchinga planina. Kreirano je 10 karata korištenjem informacija iz TerraClimate skupa podataka: padavine, vlaga zemljišta, Palmerov indeks suše (Palmer Drought Severity Index PDSI), kratkotalasno zračenje, deficit i anomalije pritiska pare, potencijalna i stvarna evapotranspiracija i brzina vetra u odnosu na nadmorsku visinu (korišćenjem GEBCO/SRTM podataka). Raspon PDSI vrednosti se kreće od -5.7 do 16.6, sa srednjom vrednošću 7.169 i standardnom devijacijom 4.278. PDSI je efikasan u kvantifikovanju suše u dugoročnom periodu. Budući da PDSI indeks primenjuje podatke o temperaturi i model vodnog bilansa, on ukazuje na uticaj povećanje temperature na sušu korelacijom s potencijalnom evapotranspiracijom. Vrednosti vlage u zemljištu Zambije se kreću u rasponu od 1 $\mathrm{mm} / \mathrm{m}$ do $413 \mathrm{~mm} / \mathrm{m}$, dok je srednja vrednost $173 \mathrm{~mm} / \mathrm{m}$. Primenjena metodologija se tehnički temelje na korištenju Generic Mapping Tools (GMT) softvera, koji predstavlja skup GIS alata baziranim na korišćenju programerskih skripti. Rad doprinosi monitoringu ekosistema Zambije predstavljanjem niza klimatskih i ekoloških karata koje su korisne za poljoprivrednu proizvodnju.

Ključne riječi: evapotranspiracija, zračenje, vlaga zemljišta, padavine, suša, pritisak vodene pare 